\title{
EVOLUTIONARY MECHANISMS OF IMPRINTING: EVIDENCE FROM TWO CASE STUDIES
}

\author{
DOI: 10.17261/Pressacademia.2019.1050 \\ RJBM-V.6-ISS.2-2019(1)-p.88-108

\section{Emre Eksi', Mehmet Erçek ${ }^{2}$} \\ ${ }^{1}$ Istanbul Technical University, Istanbul, Turkey. \\ eksi.emre@yahoo.com, ORCID: 0000-0003-0356-3231 \\ 2 Istanbul Technical University, Istanbul, Turkey. \\ ercekme@itu.edu.tr, ORCID: 0000-0002-5212-7121
}

Date Received: January 26, 2019

Date Accepted: June 10, 2019

To cite this document

Eksi, E., Ercek, M., (2019). Evolutionary mechanisms of imprinting: evidence from two case studies. Research Journal of Business and Management (RJBM), V.6(2), p.88-108,

Permanent link to this document: http://doi.org/10.17261/Pressacademia.2019.1050

Copyright: Published by PressAcademia and limited licenced re-use rights only.

\section{ABSTRACT}

Purpose- The aim of the study is to contribute to the recently developing field of evolutionary economic geography field by developing a synthetic theoretical framework to explain the evolutionary dynamics of regional clusters. The theoretical framework combines elements of multi-level imprinting theory and general Darwinism to model how hereditary factors and environmental influencers interact to render regional clusters more receptive or immune to triggering conditions.

Methodology- The study employs historical-comparative analysis (HCA) to highlight the influence of past events and reveal evolutionary mechanisms based on two cases of regional clusters from the empirical literature. Evidence from each case is used to identify the mediator and reinforcing mechanisms of imprints.

Findings- The analysis of two empirical case studies significantly corroborated our theoretical insights and displayed a considerable fit with our proposed analytical model. Not only our understanding towards variation, selection and retention mechanisms is enhanced, but also the conditions that affect the success of imprinting are identified.

Conclusion- Empirical cases illustrated that sensitive periods do not automatically result in evolution of a cluster. For a successful imprinting during a sensitive period, the presence of a VSR mechanism is necessary. VSR mechanism, on the other hand, is found to be affected by both environmental factors and genetic/hereditary factors. Additionally, MLIT should be revisited to include political influencers, which seems to be a potent environmental source of imprinting.

Keywords: General Darwinism, imprinting, economic geography, regional development history, regional growth. JEL Codes: B25, B52, R11

\section{INTRODUCTION}

Over the past three decades, key theoretical developments have pushed the analysis of regional economic change and evolution to the center stage in the field of economic geography (Martin and Sunley, 2015). Particularly, economic geographers have moved away from the static interpretation of locational economic analysis and discovered insights from more dynamic forms outside the mainstream economics (see Martin and Sunley, 2001; Bathelt and Glückler, 2003; Martin and Sunley, 2017).

Since the early- to mid-1990s well known economist Paul Krugman and his followers formalized elegant economic growth models and labelled them as 'New Economic Geography', which explains the location choices of firms through dynamics and competitiveness of the economy. At the same time, as an influential business economist, Michael Porter, manifested his wellknown 'diamond model' to capture the impact of spatial facets on the productivity of firms in order to explain the competitive dynamics of the economy. Since their interest has been on the process of spatial agglomeration of economic activities as a source of increasing returns, they both neglect the importance of history in the economic landscape. On the contrary, the geographic 
distribution of resources and potentials for development are shaped by historical factors (Capello, 2011), concentrating the research attention on the mechanisms by which geographical landscape evolves over time.

Moreover, neither local development theories like 'The growth pole theory' (Perroux, 1955); 'Milieux innovateurs' (Camagni, 1991; Maillat et al., 1993), Learning region (Lundvall, 1992) nor growth theories like 'New economic geography' (Krugman, 1991), 'Endogenous growth model' (Lucas, 1988; Romer, 1986) suffice to represent complex evolutionary dynamics of regional clusters. As a consequence of 'evolutionary turn', evolutionary approaches in economic geography have gathered increasing support and evolutionary concepts such as path-dependence, imprinting, variety/selection and complexity theory have become increasingly popular among economic geographers (Boschma and Van der Knaap, 1997; Rigby and Essletzbichler, 1997, 2006; Storper, 1997; Amin, 1999; Essletzbichler and Rigby, 2005a, 2005b; Martin and Sunley, 2006; Boschma and Frenken, 2006; Marquis and Tilcsik, 2013).

Evolutionary Economic Geography not only complements neoclassical and institutional works of analysis in the economic geography but also explains the spatial evolution of firms, industries and regions through a variety of approaches (Boschma and Frenken, 2006). However, in spite of the surge in the number of studies in economic geography, which take an evolutionary perspective, researchers are still far from formulating a coherent and holistic view of the phenomenon (Essletzbichler and Rigby, 2007).

This study aims to contribute to the debate on the evolution of regional clusters by advancing ecological frameworks, which build over analogies between evolutionary biology and evolutionary economics. In this vein, the study not only extends the main debates offered by multi-level imprinting theory (MLIT) to model how regional clusters emerge, establish and perish based on environmental changes occurred in historical time (Marquis and Tilcsik, 2013), but also contributes to the drawing of an evolutionary model of economic dynamics. The convergence of MLIT and concepts, which are clearly defined in evolutionary biology, may significantly enhance our theoretical lenses to address the extant gaps in existing theoretical arguments.

Much of the distinctiveness of the approach derives not just from giving primary emphasis to the 'historical unfolding' of the economic landscape, but also from the deliberate exploration and use of explicitly evolutionary concepts, analogies and metaphors inspired by evolutionary ideas, developed in biology, physics, ecology and related fields of enquiry.

Accordingly, the study focuses on clarifying mechanisms that mediate the success of imprinting process, thereby opening up the black box of how clusters of firms become receptive or immune to certain variations in their environments. In the vicinity of the nature vs nurture debate, the study reveals how heredity factors (nature) incorporate with environmental influencers (nurture) and introduces the main concepts and mechanisms of General Darwinism (GD) to lay the foundation of the basic evolutionary engine: variation, selection and retention processes.

The study, in so doing, presents MLIT and its proposed stamping mechanisms to introduce the dynamics of discontinuous change processes built over sensitive periods. The extensions to the MLIT, mainly, explains how the logic of MILT incorporates with evolutionary mechanisms to stamp clusters of firms and retention mechanisms, which enable perpetuation of the imprints. To substantiate its theoretical arguments, the study briefly revisits two empirical case studies, namely the British Motor Sports Industry (Pinch and Henry, 1999) and Leipzig Cultural Production Industry (Bathelt and Boggs, 2003) to help readers digest how environmental triggers affect or fail to affect clusters, and how changes in each cluster are reproduced or dropped. The study concludes by discussing the contributions made to the evolutionary economic geography approach to clusters through its dialogue with evolutionary theories developed in biology with reference to the MLIT framework.

The paper is organized as follows. Section 2 provides the literature review highlighting the importance of 'Evolutionary turn' and contribution of evolutionary concepts within the economic geography. In the section 3 , the link between environmental influencers and evolutionary process is discussed and a conceptual model explaining evolutionary mechanisms is described. In the following sections, two cases from the empirical literature are revisited and evidence from the cases is used to identify evolutionary mechanisms. Lastly, results are discussed, and conclusion is presented

\section{LITERATURE REVIEW}

One of the major obstacles of economic geography is that embeddedness of regions in their environmental landscape is often overlooked and clusters are modeled as isolated entities (Breschi and Malerba, 2001). Porter (1990) has acknowledged the role of historical events (like wars or natural disasters etc.) in his work on industrial clusters, but instead of opening the black box of such ruptures and explaining the casual mechanisms, he generalizes them as chance factors. On the other hand, there has been accumulating evidence suggesting that the existence and spatial behavior of regions can be understood through analyzing their 
dynamics over time (Audretsch and Feldman 1996; Pouder and St. John 1996; Menzel and Fornahl 2009; Ter Wal and Boschma 2011) and regions may be understood as products of history (Martin and Sunley 2006). 'Evolutionary turn' is both promising a new way of thinking about uneven geographical development and presenting an opportunity for linking different concepts and theoretical approaches from different schools of thoughts.

\subsection{Evolution of Regions}

Studying patterns of economic activities across space showed that the development of economic geography perspective and evolutionary approach complements the field of economic geography by revealing historical processes, which have produced these patterns (Frenken and Boschma, 2007). Evolutionary theory explains a current state through history, as Dosi (1997, p.1531) stated 'the explanation to why something exists intimately rests on how it became what it is'.

Industry life-cycle studies pioneered by Griliches (1957), Abernathy and Utterback (1978) and Klepper (1996) constitute an important place in the body of work. These studies generally model the focal spatial collective in four stages: emerging, growing, sustaining, and declining and analyze different dynamics of each stage. According to Lifecyle models there exists a high level of technological and market uncertainty during the initial stage, resulting in competing designs with high rates of entry and exit. When a winning model emerges, heterogeneity narrows rapidly, selection pressure intensifies, entry rates fall, and market concentration increases (Essletzbichler and Rigby, 2007). Although this perspective provides cues about evolutionary dynamics, it does not clarify the interplay between environment and focal entity, including deliberate manipulation of powerful actors and uneven competitive struggles during emerging stage. Moreover, regions may face technological and market uncertainty periods in different stages of their life cycle. Furthermore, during the initial stage of development, existing or related regional labor markets and knowledge institutions may facilitate the ability of particular regions to establish new high-tech industries (Boschma and Knaap, 1999). Therefore, history and environmental conditions should be analyzed in a more comprehensive manner rather than stage by stage basis.

Staged approach is not well matching the evolutional reality and the major external shocks forces system changes in a quick and dramatic way in the evolutionary process. There are several studies in external economies indicating more than one long-run equilibria. Not only economics but also institutionalists realize that there is plurality of equilibriums. Paleo-biologists Gould and Eldredge's (1972) landmark work on punctuated equilibrium (or 'homeostatic equilibria as they call it) shows that the evolution occurs in rapid steps in a short period rather than a slow transformation. From institutional perspective, institutional change means going from one state of common parameter values (like salient patterns of social interactions, shared beliefs) associated with a particular equilibrium to another equilibrium (Aoki, 2000). In the long run, as a result of this punctuations and cyclic interplay between environment and focal entities, distant populations will tend to develop different characteristics and possess distinct histories of development.

Consequently, an evolutionary perspective is essential to develop a fuller understanding of such issues as the geographies of technological progress, dynamic competitive advantage, economic restructuring, and economic growth. In this context, there is thus considerable scope and potential for applying and extending the ideas from evolutionary economics to the analysis of regional development. The recently developing field of evolutionary economic geography tries to explain not only how economic landscape changes over historical time but also how geography matters in determining the nature and trajectory of the evolution of economic system (Boschma and Martin, 2010).

\subsection{Evolutionary Economic Geography}

The basic concern of evolutionary economic geography is with the processes by which the economic landscape - the spatial organization of economic production, circulation, exchange, distribution and consumption - is transformed from within over time (Boschma and Martin, 2010). Evolutionary economic geography (EEG) enhance our understanding towards the development of clusters. Industries have roots in pre-existing economic and institutional structures, which orient the behavior of socio-economic actors in the present by specifying initial conditions of resources and interests (Martin and Sunley, 2006). Factors shaping cluster evolution are pre-existing industrial structures, technological conditions and institutional settings, which change through external shocks such as new technologies or market shifts (Belussi and Oliver, 2016).

Modern evolutionary economic theory emerged in the 1970s based on issues that is less addressed by the neoclassical economics (Nelson and Winter, 1974, 1982), including technological change (Arthur, 1983), the role of institutions (Hodgson, 2001) and economic growth (Nelson, 1995). The fundamental purpose of evolutionary economics is to understand the influencing mechanisms of firm behavior in a market environment, in which they function (Nelson and Winter, 1982). There are three main 
approaches identified by Boschma and Martin (2010) for analyzing the evolution: Path dependence, complexity theory and generalized Darwinism. Even though path dependence has significantly contributed to evolutionary economics via emphasizing the historical dimension, the process of path creation is still unclear. In other words, why certain alternative paths are chosen, whereas others disappear remains to be developed (Martin and Sunley, 2006).

Historical 'triggering' events based on 'chance' factors represent the central notion of path dependency theory. According to Martin and Sunley (2006, p.424):

"Most path dependent models explain the initiation of paths in terms of (small) events that are in some ways exogenous to, or orthogonal to, the key system properties. Typically, these events are described as being 'chance', 'serendipitous' or simply as 'historical accidents'. This would seem to suggest that there are innumerable different possibilities and that the preceding sequence of events (past history) plays no role in determining what new 'historical accident' occurs or whether or not it initiates a new techno-economic path; that is, paths emerge from a chaotic swirl of random events."

Complexity theory represents another promising branch to study economic geography. Beinhocker (2006) suggests the use of 'complexity economics' as an umbrella term for synthesized theoretical and empirical work linked to 'complexity thinking'. Beinhocker (2006) defines complex economics systems as open, dynamic, nonlinear systems, which are far from equilibrium. These systems are operated with agents, who are prone to errors and biases. These agents also tend to learn and adapt to unfolding conditions via networks of relationships that change over time and suggests that there is no distinction between microand macro-economics as macro patterns are emergent results of micro-level behaviors and interactions. On the other hand, it is almost impossible to explain the lasting impact of environmental influencers by only focusing on the micro-adaptive nature of complexity theory. Dopfer et al. (2004) suggested that macro level is the population or deep structure of meso-rules, which defines how rules co-ordinate with each other, and includes origination, diffusion, adaptation, retention and replication mechanisms. These meso units are the dynamical building blocks of an economic system and regional economic change depends on understanding how these rules, which are composed of knowledge connections, emerge and are institutionalized in particular regions (Dopfer et al. , 2004). Consequently, the micro orientation of complexity approach and its pitfalls to explain dynamic change of regional clusters requires scholars to concentrate their efforts to find better fitting theoretical solutions. In this vein, GD offers an interesting avenue to explore in terms of its keen focus on biological analogies and dynamic stance.

\subsection{Generalized Darwinism in Evolutionary Economic Geography}

Generalized Darwinism offers an appealing approach for evolutionary economics and its extension into economic geography. GD asserts that the core principles of evolution provide a general theoretical framework for understanding evolutionary change in all domains (from physical to social systems), but the meaning of those principles, and the way that they operate is specific to each domain (Hodgson, 2002; Hodgson and Knudsen, 2006).

There are strong conceptual links between GD and understanding organizational collectives from an evolutionary perspective. Darwin's evolutionary theory explains how populations change over time. Here, the mechanism of variation, inheritance and selection, producing a cycle of fitness in a given population. Akin to the idea, Darwinism makes comparisons between market competition and the struggle for survival based on natural selection, which is present in the animal world.

Instead of assuming that the mechanisms of social and biological evolution are similar, GD suggests that there is a degree of ontological communality between them, as the Darwinian principles apply both to biological and social systems (Hodgson and Knudsen, 2010) On this basis, the mechanisms of Darwinism (variation, selection and retention/inheritance) can help us to determine the sources of growth or survival of firm collectives from a historical standpoint. Understanding economic evolution of regions from the approach of GD requires understanding of how key concepts (variation, selection and inheritance) shall be operated in within a dynamic system of economic geographies.

\subsection{Multi-level Imprinting Theory (MLIT)}

The concept of imprinting emerged in 19th century with the studies of British biologist Douglas Spalding, who reported common behavior of birds that tend to follow the first-seen moving object in their early life. After that it was Stinchcombe's (1965) seminal work, which describes the stamps of the environment on an organization in its early phase and how these stamps persist after this early phase in spite of subsequent environmental changes (Johnson, 2007; Marquis, 2003). The concept of imprint has been utilized in different branches of organizational research like organizational ecology,(Carroll \& Hannan, 1989; Swaminathan, 1996), network analysis (McEvily, Jaffee, \& Tortoriello, 2012) or institutional theory (Johnson, 2007; Marquis \& Huang, 2010). Marquis and Tilcsik (2013, p.199) describes imprinting as: "a process whereby, during a brief period of susceptibility, a focal entity develops 
characteristics that reflect prominent features of the environment, and these characteristics continue to persist despite significant environmental changes in subsequent periods."

As stated above there are three essential features of imprinting, namely, the presence of a sensitive period, the powerful impact of environment and persistence of stamped characteristics beyond the sensitive period (Marquis and Tilcsik, 2013). Sensitive periods are conceptualized as brief periods of significant transition and there is the possibility of multiple sensitive periods in the life-cycle of an entity. Imprinting theory resembles punctuated equilibrium perspective, as both refers to brief discontinuous periods of intense change and link them with the changes in environmental conditions.

In the multilevel view of imprinting Marquis and Tilcsik (2013) offers four sources of imprinting mechanisms, namely, economic conditions, technological conditions, institutional factors and individuals. The environment is conceptualized by Marquis and Tilcsik (2013) as rich and modular with a hierarchical depth. There are several empirical studies showing that organizational collectives, which are stamped by imprints carry these imprints of their founding environment, rooted in economical, technological and institutional conditions or stamp of an entrepreneur. Table 1 below shows sources of imprinting mechanisms with given examples.

Table 1: Source of the Imprints on Organizational Collectives (Marquis and Tilcsik, 2013)

\begin{tabular}{|l|l|}
\hline Source of Imprint & Mechanisms \& Examples on Organizational Collectives \\
\hline $\begin{array}{l}\text { Economic and } \\
\text { technological } \\
\text { conditions }\end{array}$ & $\begin{array}{l}\text { 1. Mechanism: External economic and technological conditions serve as a constraint on new } \\
\text { organizations, and the initial patterns are maintained by subsequently founded } \\
\text { organizations imitating prior organizations. } \\
\text { Example: Stinchcombe (1965) on employment structure of different industries; Marquis } \\
\text { (2003) on travel technology influencing the density of local inter-corporate networks }\end{array}$ \\
\hline Institutional factors & $\begin{array}{l}\text { 2. Mechanism: Collectives have different standards of legitimacy that not only shape initial } \\
\text { organizations, but also continue to influence more recent entrants. } \\
\text { Example: Lounsbury (2007) on different corporate strategies of investment firms across US } \\
\text { cities; Dobbin (1994) on different organizational types of railroad firms across countries. }\end{array}$ \\
\hline Individuals & $\begin{array}{l}\text { 3. Mechanism: Political leaders and influential founders create powerful policies or } \\
\text { organizations that define the arrangements and templates of a field or industry in an } \\
\text { enduring way } \\
\text { Example: Mao Zedong's ideology of self-reliance having a lasting influence on industrial } \\
\text { structure in China (Raynard, Lounsbury, \& Greenwood, 2013); Rockefeller developing the } \\
\text { vertically integrated oil industry through Standard Oil (Chernow, 1998) }\end{array}$ \\
\hline
\end{tabular}

The original model of multilevel imprinting depicted in Figure1 represents multiple sensitive periods and defines environment as a varied, $n$-dimensional space with economic, technological, institutional conditions and individual influencers. The first block on the Figure1 presents the first sensitive period of cluster: foundation. During foundation cluster is vulnerable to its environment. Environmental forces emerge from economical, technological and institutional sources or surface because of the influence of individuals and stamp their mark during the early years of the cluster. Second part shows the imprint persistency. During the nonsensitive period the stamp of foundation is still carried by the cluster. Imprinting process might occur multiple times during a life course and the last section of the model illustrates other possible multiple sensitive periods. During a new sensitive period, different forces come into play and lead to either a new imprint, modification, replacement or decay of the existing imprint. As described in the multi-level imprinting theory, according to Marquis and Tilcsik (2013) the factors that contribute to the persistence of imprint over time are namely the limited learning in the non-sensitive period, the lack of competitive threat, taken for granted nature of status quo and inertial forces (e.g vested interests). 
Figure 1: General Model of Multilevel Imprinting,

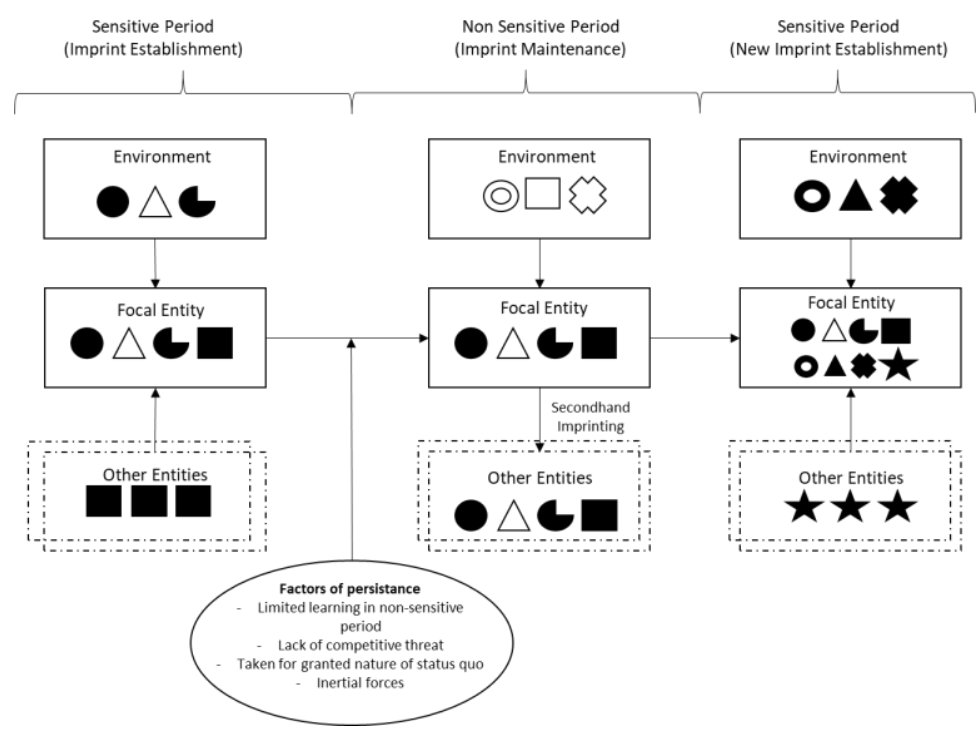

Source: Marquis and Tilcsik (2013)

Even though MLIT offers a rich insight based on environmental influences and emphasizes a dynamic process of multiple imprints, which adopts a historical view, it still suffers from a series of shortcomings. Only recognizing that history matters does not help to understand how it matters (Jones \& Khanna, 2006; North, 1990). To date, much research has focused the features, sources of imprint and how they are persisted. Less attention has been given to the explanation of imprinting process through evolutionary mechanisms. General model of imprinting is a promising and powerful approach to address how environment contributes to the evolution of a focal entity in a multidimensional way, but it cannot explain why some imprinting attempts or powerful environmental conditions fail to cast their mark on the focal entity even if there is a sensitive period. Marquis and Tilcsik (2013) adverted some mechanisms like "window of imprintability" or emulation of imprint, but these mechanisms are not explained in their model explicitly. Considering the model, there are four fundamental research opportunities are located:

First, even though MLIT assesses the imprints in different levels, the model is unidimensional and works for each level. For example, when an organization collective is under study, it does not reveal how organizational level variations subsequently translate into population imprints. The model treats collective as a whole without considering that collective is also the sum of all organizational members.

Second, not every imprinting attempt by the environment stamps its mark, therefore it is necessary to reveal how the characteristics of environment pass to the focal entity in a more comprehensive manner. To locate an imprint, tracing the blueprints of focal entity is necessary, the imprinting process can be understood through explaining how hereditary factors that defines all explicit and implicit characteristics of a focal entity interact with environmental variables. In this way, we can reach a fuller understanding of the triggers, enablers, mechanisms in pattern formation, which are not described in the original model of multilevel imprinting.

Third, explaining WOI is necessary to capture the underlying causes in the particular case, where imprinting factors favor one region to another as well as the elimination of firms and their routines previously sheltered from environmental conditions. Thus, an evolutionary type of explanation about how imprinting factors favor one region over the other is necessary.

Lastly, features of the emulation mechanism and inheritance of imprints need further conceptualizing in the model. Marquis and Tilcsik (2013) explained that the patterns, which are established during the sensitive periods are then perpetuated by subsequent organizations' emulation of the older members residing in that collective. This process is defined as the secondhand imprinting, but the sub-mechanisms of secondhand imprinting is not defined. Thus, an evolutionary approach is necessary to explain the diffusion of imprinted elements, and how variation of few firms amplifies an imprint on the population scale. 
In the next section, our aim is to conceptualize a refined model based on an evolutionary perspective to further investigate these black spots. Distinguishing evolutionary mechanisms and how they operate in different analytical levels will help us to understand a holistic picture of the collective interaction of environment and organizations.

\section{CONCEPTUAL MODEL}

\subsection{Linking Evolutionary Process and Environmental Influencers}

A framework explaining the evolution of cluster through linking evolutionary process and environmental underpinnings would enhance our understanding towards how imprinting theory works in organizational collectives. This study is one of the very few attempts to address evolutionary mechanisms that influence cluster of firms, but also it offers the blending of two different evolutionary approaches, namely, Imprinting Theory and General Darwinism.

As we have previously discussed, MLIT, originated from biological ecology, has considerably leveraged our understanding towards how historical environmental influencers leave their mark on focal entities (e.g. organizational collectives). Yet, biological ecology also tells us that nurturing (environment) is not the only influencer shaping entities, as nature (genes and hereditary factors) is another strong influencer in the process. Hull, Langman and Glenn (2001) argued that both gene replication and interaction between the organism and its environment play part in the evolutionary process. Nature is, therefore, a highly referred influencer in the evolutionary economic geography under generalized Darwinism literature. As one most fertile approach to use ideas and concepts in evolutionary economic geography, variation, selection and retention can also highlight the causality about the conditioning factors embedded in the imprinting process.

Since it is hard to identify whether heredity or environmental influencers are responsible for a particular trait of a focal entity, most researchers acknowledge that both nature and nurture influence the behavior and its developmental patterns. If we accept the ontological communality of biological and social domains, then the application of it in the social domain should highlight how rules of nature (General Darwinism and others) work with rules of nurture (Imprinting). We suggest that in order to understand what constitutes suitable social interactors and how interaction with the environment results in a potential selection should be carried to the domain of organizational collectives. By enhancing imprinting theory with variation, selection, retention (VSR) mechanisms in the Figure 2, the basis for the analytic framework, which explains how clusters are shaped by unfolding events in history, can be established.

Figure 2: Imprinting on Organizational Populations, VSR Mechanisms and Window of Imprintability

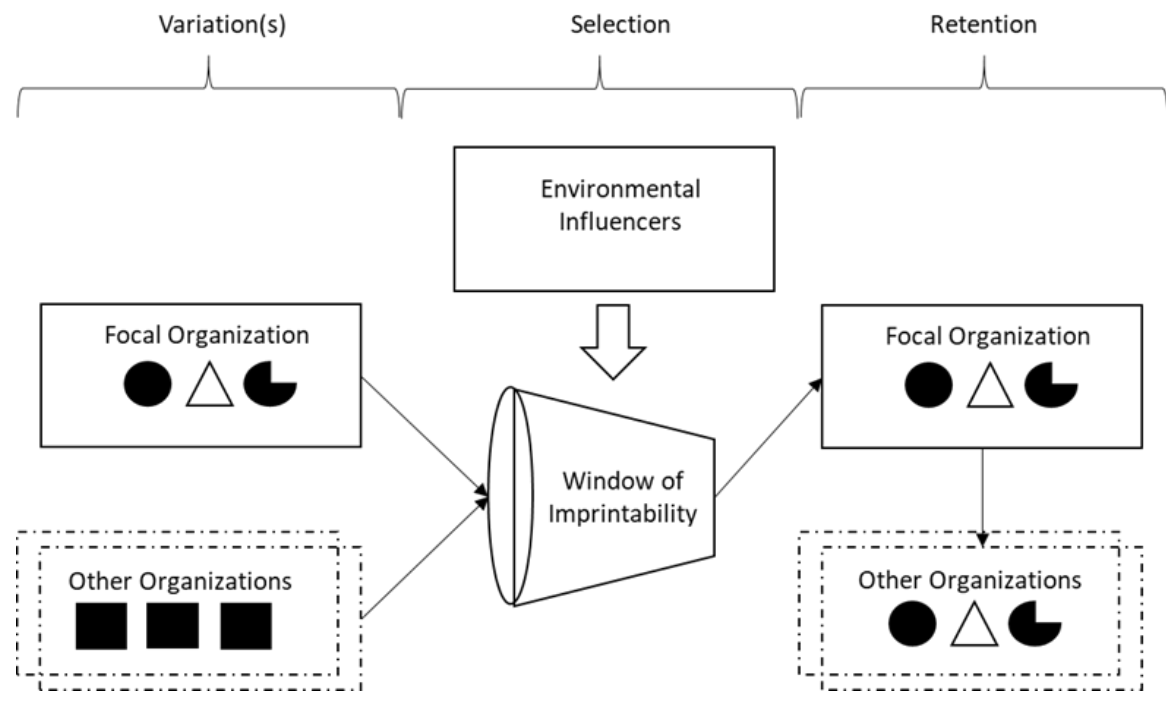


The imprinting requires a sensitive period. Temporary conditions, shocks, as well as historical 'accidents' may create this sensitive period, but the main indicator to be classified as sensitive period is increased malleability of focal entity by environmental conditions than in normal times. During the foundation a focal entity is often vulnerable to its environment and environmental forces. Although, it is well established that there may be multiple sensitive periods within the life cycle of a focal entity, foundation represents a recurrent stage for sensitivity due to the scarcity of both symbolic and material resources.

The window of "imprintability" is only open during the sensitive periods as economical, technological, institutional conditions and powerful individuals try to stamp their imprints on a focal entity within a cluster. However, not every environmental influencer succeeds to put its stamp in this brief sensitive period. Hereditary factors apart from environmental ones play an important role in the selection. Thus, understanding the mediation dynamics in the selection and retention mechanisms are important to locate the success factors of imprints at the cluster level. The last step of the imprinting process is retention as the retention mechanism carries the impact of the imprint to the critical mass via replication and/or diffusion. During the retention step information (features) concerning adaptations is passed on to other entities in the cluster. Retention step leads imprint persistency through local spin-offs and localized learning.

The original multilevel imprinting model explains the imprinting in only three steps: Existence of a brief sensitive period, imprinting with a powerful impact of the environment and persistence of the characteristics developed during the sensitive period. In the next section we complement the original MLIT steps with evolutionary mechanisms of VSR.

\subsection{Variation}

Variation is generated through transformation and emergence of new properties and provides the fuel for evolutionary change. Without variation, the population would be stuck in equilibrium (Hodgson 2001; Essletzbichler, 2012). This change could be the result of random mutation, Schumpterian entrepreneurial actions, recombination of existing characteristics, routines or importation of new characteristics from other places (Essletzbichler, 2012). In any manner, variation is necessary for selection to occur. After variations occur, selection process operates on the variations. In order to understand why certain varieties survive, we need to understand the selection mechanism.

\subsection{Selection}

Selection entails that those interactors with traits that fit the locally and historically specific environmental context better are characterized by higher survival rates, and, in turn, higher rates of replicative success. Darwinism offers an algorithmic logic predicated on a feedback loop between variety, inheritance and selection that can explain adaptive complexity. A general description of the selection process is made by Hodgson and Knudsen (2010, p.92): "Selection involves an anterior set of entities that is somehow being transformed into a posterior set, where all members of the posterior set are sufficiently similar to some members of the anterior set, and where the resulting frequencies of posterior entities are correlated positively and causally with their fitness in the environmental context. The transformation from the anterior to the posterior set is caused by the entities' interaction within a particular environment". Here, selection does not have to lead to the most efficient outcomes. Beyond that, cooperation is at least as important as competition considering multilevel (or group) selection processes (Sober and Wilson, 1998)

As stated by Price (1995) subset of elements from an anterior set is selected and this selection changes the composition of a population. After an industrial crisis or shock a group of firms from anterior set are selected (selection of interactors) and this selection will result not only in the elimination of some firms but also the removal of their routines from the population (selection for replicators) because the selection process will not stop until variation disappears, and changes in population are caused by a systematic interaction between fitness and survival (Essletzbichler, 2012).

There are two complexities related to selection process for firms or firm groups. First, selection as a result of changes in the environment could work on multiple traits of entities, which makes the selection process more complicated. Second, survival of firms also depends on their adaptability in response to the changes observed in the environment. The environment is not totally exogenous to the firm and the interaction of firms or group of firms with their environment represents an important factor for the selection process.

\subsection{Retention / Inheritance}

Selection process is followed by replication process, which creates the new path for the surviving subset. The inheritance refers to a different mechanism, including diffusion and other forms of replication, by which information concerning adaptations is passed on or copied through time (Hodgson and Knudsen, 2010). 
The environment acts directly on interactors but not replicators. Yet, the role of replicators (e.g. routines) on social interactors (e.g. firms) under pressures of the particular environmental context, in which the interactor operates, is important for understanding the retention process. A replicator is a structure hosted by the entity, which is causally involved in the replication process. The frequency of similar replicators within the population is increased and the fitness in social evolution is achieved through either by diffusion of replicator to other interactors (eg. knowledge spillovers, localized learning) or by making copies of the interactor (e.g. spin-offs), by this way the characteristics of the interactors are passed on by replicators (Essletzbichler, 2012).

As stressed by Essletzbichler (2012), replicated information by itself is inadequate to provide a complete description of the emerging interactor, as the replicator does not replicate by itself but includes building instructions for the development of interactors that are stimulated by particular environmental conditions. The information that makes the copy entity similar to its source is obtained during its creation. Since the environment does not act on (recognize) replicators directly, replicating entities are not manipulated directly by the environment and for this reason, information (adaptive experience) is able to accumulate over generations (Essletzbichler, 2012). The replicators related for each interactor are relatively durable compared to their host interactor, in an example, routines, apprenticeship are passed on other firms and continues even if individual firms hosting them do not survive.

Applying GD to economic geography then requires an understanding how the abstract principles of variation, selection and inheritance can be operationalized to explain the historically specific, inconstant and differentiated geography of capitalism. GD is not contradicting but complementing existing work in EEG (Essletzbichler, 2012). How industries emerge and develop across space, how regional economies function as 'selection' environments, how far and in what ways various 'retention' mechanisms reinforce spatial patterns of economic activity require aggregation and synthesis of different approaches. Accordingly, we will try to solidify how mechanisms of VSR can be integrated with the mechanisms of MLIT to better explain the evolutionary dynamics of specific clusters. The next section details our historical comparative analysis framework and selection of historical case studies to empirically illustrate the operationalization of the aforementioned mechanisms.

\section{DATA AND METHODOLOGY}

In our study, we argue that in order to enhance our understanding about the spatial behavior of cluster, there is the need to uncover its specific evolutionary path, which is based on relatively sensitive and insensitive periods and a multitude of imprints. This effort needs exploring the cluster as a contextually bounded system over time. Moreover, the enhanced framework established to develop the imprinting phenomena suggests that deep understanding of the mechanism with its mediators requires using comparative cluster cases, each based on rich historical data. Comparisons between clusters is necessary to demonstrate the causality between changes in economic and social landscape over historical time and the trajectory of the cluster. From this perspective, historical-comparative analysis would help us to enhance our insight.

Historical-comparative analysis (HCA) is an important research approach in the social sciences, especially in political science and sociology, which often works at the meso- or macro-level and employs variety of comparative and within-case methods (Lange, 2014). Influenced by pioneers like Adam Smith and Max Weber, HCA methods have been applied for a long time to analyze scientific revolution, social change, and democratic movements during the nineteenth century. HCA emerged as a new research tradition specifically after 2000s (Mahoney and Rueschemeyer, 2003). Small number of comparative cases and within-case analysis are two of the most distinguishing features of HCA, which tend to positively influence each other in terms of validity and reliability (Lange, 2014). Even though narrative studies have a disadvantage in generalizing causal arguments, they possess several advantages (Abbott, 1995; Mahoney 2000; Rueschemeyer and Stephens, 1997) like: (1) comparing a holistic phenomenon; (2) indepth understanding of actual path leading to the results; (3) highlighting the influence of past events; (4) analyzing mechanisms.

As Yin (2003) eloquently expressed, case studies are often utilized when researchers deliberately want to uncover the influence of contextual conditions on the phenomenon of the study. Thus, in terms of our focus, type of problem and unit of analysis a historical case study research becomes the most convenient approach for the study. HCA mostly utilize secondary data sources like written historical books, articles, eyewitness accounts, life stories. As a qualitative research approach, reliability is much more about consistency and validity is related to authenticity (Neuman and Robson 2014). In the next section, two cases from the empirical literature are revisited, evidence from the cases is used to identify the mediators and reinforcing mechanisms of imprints. Once mechanisms are clarified their relations with the contextual conditions are also unraveled.

The first case is written by Steven Pinch \& Nick Henry (1999), entitled "Paul Krugman's Geographical Economics, Industrial Clustering and the British Motor Sport Industry". In their article, Pinch and Henry originally examine the applicability of Krugman's ideas for explaining the geographical cluster of British motor sport industry and its remarkable upsurge. They argue that Krugman's 
emphasis upon accidents of history and external economies of scale provides only partial explanation for the evolution of this cluster and underrepresents potential explanations offered by the social constructionist processes. The case data are based on face to face semi structured interviews with 50 senior managers, designers, engineers and enormous secondary data gathered from literature surveys on car racing industry, biographies and professional journals.

The second case is written by Bathelt and Boggs (2003) and titled "Towards a Re-conceptualization of Regional Development Paths: Is Leipzig's Media Cluster a Continuation of or a Rupture with the Past?". In their article Bathelt and Boggs examine the evolution of two media industries in Leipzig, Germany, namely the new TV/ film production and interactive digital media cluster and the old book publishing media cluster. These clusters are shown as connected structures, indicating the continuing history in media industries of Leipzig. On the other hand, Bathelt and Boggs (2003) argue that technological and political crises act as mechanisms, which rupture the regional development paths and trigger localized learning as the driver of economic growth.

\section{FINDINGS AND DISCUSSIONS}

\subsection{Case One: British Motor Sport Industry (BMSI)}

This industry is located around Oxfordshire in England and considered as "Motor Sport Valley". Approximately 75\% of the total single seated racing cars including Formula One, Indy Racing League, Championship Auto Racing cars are designed and manufactured in this cluster, which hosts small, flexible, technologically sophisticated companies, with a high degree of export orientation (Pinch and Henry, 1999). Between WWI and WWII there was no British-designed and manufactured car participating in a grand prix race in Europe. Right after the WWII Italian companies such as Ferrari, Alfa Romeo and Lancia began to dominate motor racing. However, within a few years, the small companies in southern England cathed up and began to dominate motor racing and maintained their pole position since then (Pinch and Henry, 1999). Aston and Williams (1996), attempted to explain the rapid rise of the BMSI through series of accidental factors, which are summarized below:

1) Accident at Le Mans racetrack in 1955, in which a Mercedes racing car spun off, resulting in 183 spectators being either killed or injured and withdrawal of Mercedes team from motor sport,

2) Unused airfields after WWII provided infrastructure for motor racers and nest for local racing clubs fostering enthusiasm and practical experience,

3) Despite the vertically integrated manufacturers like Ferrari and Porsche, which are building cars exclusive to their own teams, British-based constructors would sell their cars to anyone,

4) The ban on cigarette advertising on British television in 1965 resulted in the channeling of their marketing expenditures to racing sponsorships, beginning with Lotus in 1968.

Explaining the rise of BMSI only through these accidental factors would be insufficient and misleading. Explaining how history plays its role on regional configuration of economic activity requires more than spotting the historical accidents. Moreover, it should also be noted that the British-based manufacturers were quite well established before the cigarette manufacturers entered the fray, so it is a consequence not an antecedent (Pinch and Henry, 1999). The withdrawal of Mercedes, utilization of unused airfields might provide a 'window of opportunity' effect but these accidents only explain the contingent characteristics of the sensitive period not the mechanism itself. In order to reveal this mechanism, referring to the imprinting theory, the whole feature set of the environment (economic, technological, and institutional) or individuals, who provide notable influence on the focal entity during sensitive periods should be examined. Pinch and Henry (1999) provides convincing explanations on the mechanism while supporting the theoretical lens of imprinting.

\subsubsection{Evolution of Motor Sports Industry and the Source of Imprint}

The history of motor racing provides a classic example of a radical shift in technology and changes on the technological conditions originated mostly from aerospace industry rather than car manufacturing (Pinch and Henry, 1999). They explain the technological superiority of British-designed cars as:

"The lightweight mid-engined racing cars produced by the British-based constructors in the 1960s were superior to the heavy, front-engined cars produced in Italy. These British-designed cars called for radically different types of knowledge to those previously incorporated into motor sport. First, there were changes in engines; large heavy units were replaced by lightweight aluminum configurations. Second, aerodynamics became essential in racing car design. Third, as weight reduction became crucial, experience in composite materials that could combine strength and weight came to the fore." 
Development of Britain aerospace industry can be traced back to governmental support for aircraft manufacturing in the $1920 \mathrm{~s}$ and 1930s under military race. After WWII, British aerospace industry remained massive in relation to the size of the country (Hebb, 1993). The table2 below shows the main aerospace-derived influences on technological innovation in the motor sports. As a result of this technological shift, the locus of the industry shifted very rapidly from northern Italy to southern Britain.

Table 2: Key Aviation-Inspired and Automotive-Inspired Innovations in Formula One Racing (Pinch and Henry, 1999)

\begin{tabular}{|c|c|c|}
\hline Innovation & Aviation Use & Formula One use \\
\hline Active suspension & Computer based control & Improved handling (banned in 1993) \\
\hline Aerodynamics & $\begin{array}{l}\text { Efficiency in the air, fuel economy, speed } \\
\text { etc. }\end{array}$ & Speed but also downforce \\
\hline Aero engines & $\begin{array}{l}\text { Combination of light weight with high } \\
\text { power output }\end{array}$ & $\begin{array}{l}\text { Combination of light weight with high } \\
\text { power output }\end{array}$ \\
\hline Aluminum & Used in aircraft structures & $\begin{array}{l}\text { Widely used in early chassis / cockpit } \\
\text { design }\end{array}$ \\
\hline Carbon composites & Used in aircraft structures & Used in monocoque construction \\
\hline Carbon disc brakes & High efficiency and light weight braking & High efficiency and light weight braking \\
\hline Carbon fiber clutch & Not directly used but aviation inspired & Light weight and strength \\
\hline Computer based telemetry & Rapid communication of technical data & Rapid communication of technical data \\
\hline Fly-by-wire & Weight saving electronic control & Weight saving throttle-by-wire control \\
\hline Turbo charging & Extra performance at high altitude & High power output (banned) \\
\hline Wind Tunnels & Testing aerodynamics & Testing aerodynamics \\
\hline Wings/ winglets & Support in the air & Downforce for grip \\
\hline
\end{tabular}

\subsubsection{Source of Variation}

The first point is to reveal the source of variation, by which the changes in environmental conditions become significant for the focal cluster. In the diamond model, which defines the microeconomic foundations of economic development, Porter (1998) highlights the importance of specialized factors that are integral to the innovation and marks trained personnel as the most obvious element in improving factor conditions. Highly skilled workers were pivotal in transferring the necesary knowledge from aerospace industry. By the 1950s, over $16 \%$ of Britain's qualified scientists and engineers were engaged in research and development in the aviation and despite the Italian industry, many of the leading designers and engineers in motor sport were originally trained in aeronautical engineering (Pinch and Henry, 1999)

\subsubsection{Selection Mechanism}

The withdrawal of Mercedes could have provided a WOI for all manufacturers in motor sports industry, but British manufacturers exploited this gap more than their competitors in Italy. This was possible through lightweight aluminum configurations and weight reduction know-how, which were acquired from aerospace connections. Contrarily, Italian Industry did not have the same amount of aircraft-inspired know-how, and as a result, powerhouse of the industry shifted from northern Italy to southern Britain (Pinch and Henry, 1999)

\subsubsection{Retention Mechanism}

As being technology driven, the new knowledge generation is crucial for motor sports industry and competitiveness depends on supremacy in this continuing process. For this very important reason, knowledge dissemination is much more important for technological imprinting cases. In the case of British motor sport industry, need for knowledge supremacy creates a frictionless reinforcement process through diffusion of aviation-inspired technologies. Knowledge about design, production and operation of racing cars are mostly possessed by designers, engineers, fitters and mechanics, and carried by them. The main knowledge dissemination processes are listed as high staff turnover, information leakage through component suppliers, high rate of new firm formation after failures, informal collaborations, information gained through personal contacts and observations during races (Pinch and Henry, 1999). Staff exchange acts as the main carrier of crucial information between companies as it is quite often in 
BMSI. Analysis of professional career histories showed that the average move during the career is eight times, which equals to 3,7 years of tenure in each company (Pinch and Henry, 1999).

It is obvious that the flourishing of BMSI is not solely based on accidental factors. Although, there were powerful endogenous factors like the presence of local racing clubs and the tradition of engineering industries, the variation that led to the technological superiority was the intervention of aerospace industry through mobilization of its factor conditions. Withdrawal of Mercedes reinforced the effect of window of opportunity, but the competitive edge of British industry was the ultimate factor that enabled it to prevail against Italian industry. In this sense, the main environmental influencer was technological conditions, not the Mercedes accident.

\subsection{Case Two: Leipzig's Media Cluster}

Leipzig media cluster, which includes different media branches consisted of 1500 firms in year 2000 (Bentele et al., 2000). Although, in national terms, Leipzig media cluster is smaller than other clusters and does not qualify as a primary media cluster, the current scale is enough to produce further agglomeration (Bathelt,2002). The media sector had 25,600 permanent employees and 14,600 freelance consultants, which amounts to about $16 \%$ of the regional labor force (Bentele et al., 2000). Survey conducted by Bathelt (2002) indicated that, most of the survey firms operates under new electronic services/interactive media branch with $35,3 \%$, followed by PR/marketing $(26,5 \%)$ and Film/TV production $(23,5 \%)$.

After the German Reunification in 1990, most industries faced with crisis and downsized dramatically due to the breakdown of the state-planned economy. The media industry of Leipzig is born in this period (Bathelt and Boggs, 2003). Since the birth of the media industry in Leipzig was very recent, most of the firms were quite young. While 115.000 workers were employed in the manufacturing/mining/construction business in 1991, this number dropped to 59.000 in 1997. By July 1999, around 19,000 workers were employed in Leipzig's manufacturing sector (Statistisches Landesamt des Freistaates Sachsen, 2000). This decline resulted in the relocation of workforce from East to West Germany, where significantly more employment opportunities existed.

Moreover, Leipzig did not have a tradition and never held an important position in radio, TV industry (Sagurna, 2000). During DDR the radio and TV industry was mostly concentrated in East Berlin - Potsdam which attracted actors, technicians and other media workers from all over the country (Bathelt,2002). This concentration in Potsdam can be recognized even today and was still referred as the center of the German Film Industry (Krätke \& Scheuplein, 2001). Despite the lack of tradition in media industry, development of new media cluster is quite interesting. Although, some of the local politicians and city planners interrelated birth of new media cluster with the pre-War book publishing industry, Bathelt and Boggs (2003) showed that the evolution of two clusters have detached paths. The evolution of Leipzig cultural production industries were analyzed in 3 main periods, first, evolution of the book publishing industry until 1945, second, book publishing industry during the G.D.R (The German Democratic Republic) and reunification, lastly birth of new media cluster in Leipzig after German reunification.

\subsubsection{The First Period: Evolution of Book Publishing Industry Until 1945}

Leipzig held a strong tradition in book publishing. The first book printer-publisher was established around 1481 in Lepizig, 30 years after the invention of moveable-type printing press, which changed the economic geography of publishing in Central Europe (Menz 1942; Schulz 1989; Schönstedt 1991). Gutenberg's invention not only integrated traditional suppliers like paper manufacturers, rag millers, page illustrators and book binders to the new industry, but also created new type of suppliers such as type-casters and press manufacturers. Thus these developments revolutionized the structure of the industry and the division of work. Subsequently, printing press diffused to all Central Europe through printers' apprentices, who sought out new urban markets (Bathelt and Boggs, 2003).

During the period of technological diffusion, Leipzig also had a main locational advantage, it had a central position in trading routes (Gormsen 1996). At the same period, Frankfurt was also one of the most important fair towns due to its central geographical location. In the 16th century, Frankfurt was also a principal book market in the Western World, but by the end of the 17th century Leipzig had dominated the book publishing (Weidhaas, 2009). By the end of 18th century, Leipzig book publishing industry developed into a Marshallian industrial district with its comprehensive competitive and complementary activities, accompanied by well integrated interregional and international markets (Boggs 2001). The reason behind the primacy of Leipzig and collapse of Frankfurt in book publishing can be understood through the analysis of the VSR mechanism. 


\subsubsection{Source of Variation}

Reformation changed the precapitalistic European social and economic order. By 1519, Luther had become Europe's most published author with 45 original compositions with nearly 300 editions. Luther personally agreed with top printers from Leipzig, and only in three years, Luther had produced around 160 writings addressing the Christian people of Germany in their own language (Pettegree, 2017). Leipzig's book printers were specialized in German dialect texts and heretical works, where Frankfurt was focused more on Latin texts. This differentiation was a heredity factor for both agglomerations, which was carried till the rupture by the Gutenberg's invention.

\subsubsection{Selection Mechanism}

Gutenberg's invention of the moveable-type printing press opened a window of opportunity for both Leipzig and Frankfurt. However, the study of Dittmar (2011) showed that the diffusion of printing press is based on the distance from Mainz. Leipzig enjoyed the window of opportunity rather than Frankfurt, since it was closer to Mainz.

Possessing cultural proximity to protestant reformation helped for publishers in Leipzig to capture the opportunity, which helped the local industry to become a major location for reformist printing since early 16th century. Leipzig's book fairs were also far friendlier than Frankfurt's to the reformationists (Bathelt and Boggs, 2003). Frankfurt's book fair, on the other hand, was mostly dominated by Latin texts with International participants. This variation worked in the advantage of Leipzig as the demand for Latin texts declined and demand for German texts surged during the next few centuries. Leipzig was attracting foreign publishers, but published increasingly more German dialect texts. (Bathelt and Boggs, 2003)

\subsubsection{Retention Mechanism}

The process, which was used to cast movable metal type mill was complex. In order to produce the suitable metal type, printers needed a type of alloy which was strong and ductile; hard and nonporous; non-corrosive and maintained the plane-parallel shape of the castings when cooled (Dittmar, 2011). This know-how was a trade secret and the printers, who established presses in cities across Europe were almost exclusively Germans. Most of them had been apprentices of Gutenberg and his business partners in Mainz, or had learned from former apprentices (Dittmar, 2011). As these apprentices looked for new urban markets, the geography of production and local economies had changed dramatically. The demand for new suppliers as type casters, press manufacturers etc. put its stamp on urban division of labor, and as a result, Leipzig not only became an important trade center but also one of the Central Europe's earliest book publishing sites (Bathelt and Boggs, 2003).

\subsubsection{The Second Period: Evolution of Book Publishing Industry during the G.D.R}

\section{(The German Democratic Republic) and Reunification}

Before the World War II Leipzig book publishing industry contained 300 book publishers, 500 allied firms and the German Library (the Deutsche Bücherei). However, during WWII $80 \%$ of all physical plants were destroyed by air strikes and skilled labor were relocated into other crucial industries during the wartime (Bathelt and Boggs, 2003). Furthermore, during GDR regime, nationalization, censorship and U.S. attraction drove away the remaining skilled workforce from Leipzig to the West zone. Not only workers but also institutions were relocated in the West. Among these institutions, which were moved to the West were Frankfurt Börsenverein (German Publishers Association) and the Deutsche Bibliothek (German National Library). Frankfurt Book fair was restored after 200 years, as Leipzig lost its status in the industry (Bathelt and Boggs, 2003). GDR was running a sovietstyle planned economy, which was blocking not only market-oriented competition, but also hindering the sophistication of the demand. Furthermore, book publishers in Leipzig became technologically underdeveloped and poorly equipped compared to their Western competitors during the GDR rule. (Karrasch 1989; Volpers 1991; Gormsen 1996; Wittmann 1999; Boggs 2001)

In 1990, after German Reunification, the Förderverein Medienstadt Leipzig (Development Association of the Media City Leipzig), initiated a program for re-development of the Graphisches Viertel as a site of book publishing and affiliated industries (Schubert, 2000) and restored the city as a major center of book publishing in Germany. The Förderverein's mission to position Leipzig as a media city with media-related businesses and institutions failed. Neither the importance of Leipzig's book fair was restored nor did publishing houses flourish. Instead the industry underwent massive de-industrialization. (Volpers 1991; Lemke 1992; Börsenblatt 1993; Bach 1995; Denzer and Grundmann 1999; Wittmann 1999; Boggs 2001; Berg et al. 2001). The political initiative didn't create any change in the cluster dimensions. 


\subsubsection{The Third Period: Birth of New Media Cluster in Leipzig after German Reunification}

Although, some of the local politicians and city planners interrelated birth of new media cluster with the pre-War traditional industry of book publishing, the birth and growth of the new media industry in Leipzig was influenced more by the establishment of MDR (Mitteldeutscher Rundfunk; or Middle German Broadcasting Service), a public television and broadcasting network (Denzer and Grundmann 1999). Moreover, Leipzig had never played an important role in the television and film industry (Sagurna 2000). The G.D.R. television and film industry had a rigid hierarchical characteristic and was concentrated in East Berlin and nearby Potsdam. Leipzig only housed a small studio during the GDR rule (Gräf 2001; Krätke, and Scheuplein 2001).

\subsubsection{Source of Variation}

Actually, the establishment of MDR in Leipzig was a political action, Leipzig was located in the center of southeastern Germany close to three German states (Länder) Saxony, Saxony-Anhalt and Thuringia. Leipzig was the only city in Saxony, which could be accepted by politicians from all states that could benefit from the investment in media sector due to its central location (Bathelt 2002). The formation of this cluster was not embedded in historical roots in the book publishing industry. It has developed by local start-ups and different facilities that served for the MDR (Berg et al. 2001). The location of new media industry was not the Graphical Quarter, which housed book publishers, but the Leipzig-Connewitz, that was located at the city's southern district (Denzer and Grundmann 1999).

MDR's foundational strategy was to outsource its functions to its separate subsidiaries and local suppliers. In order to accomplish this strategy MDR called for experts from different professions like film teams, technicians, cutters, reporters, news agencies and other media specialists from other regions to establish a branch in Leipzig and offered them long term contracts (Bathelt 2002). By this way, suppliers and service providers forced to establish their branches in Leipzig and they brought professional expertise to the region. Establishment of MDR triggered the development of specialized competencies, which, in turn, initiated other startup activities from within the region (Bathelt 2002).

\subsubsection{Selection Mechanism}

Although Leipzig did not possess capabilities required by TV and film industries, the new media industry developed around MDR, which became the anchor organization in the cluster (Sagurna 2000; Schubert 2000; Bathelt 2001). The cluster firms were deeply connected with MDR and with each other. Furthermore, they were also connected to other actors in the region like new Leipzig convention center, which indicated that there were strong vertical relations between the firms of the cluster. After its establishment, MDR rapidly became the anchor organization in TV and media industry in Leipzig, which was the one of the few economic sectors that grew in the post-Reunification period (Sagurna 2000; Schubert 2000; Bathelt 2001). Here, as opposed to the old publishing industry case of Leipzig, new firms that were established around MDR were subject to a selection mechanism within the cluster rather than between clusters.

\subsubsection{Reinforcing Mechanism}

The new media industry was born through the re-organization of Leipzig's local assets and interactive learning. The industry became one of the few economic sectors that helped Leipzig's economic growth after the reunification. The education institutes which supported local learning during the process are listed below (Bathelt 2002).

1. The University of Leipzig (Institute for Communications and Media Studies)

2. Hochschule für Technik, Wirtschaft und Kultur (HTWK-College for Technical, Economic and Cultural Studies)

3. Hochschule für Graphik und Buchkunst (College for Book and Graphic Arts),

4. Fachschule der Deutschen Telekom (German Telecom Training Centre),

5. Fernsehakademie Mitteldeutschland (Middle German TV Academy),

6. Medienakademie Leipzig (Media Academy Leipzig)

7. Sächsische Akademie der Werbung (Saxon Marketing Academy)

The higher education institutes and special training programs not only supported the creation of specialized knowledge base in media but also they enabled the accumulation of practical experience through joint research projects with media firms from TV and film production, multimedia and internet applications (Bathelt 2002). The graduates from these institutions created a specialized knowledge base in a wide variety of media-related fields. The students were able to gather practical experience during their studies and conducted research projects together with local media firms, especially in the area of TV and film activities and multimedia and internet applications. Moreover, another way to gain practical experience for many students was having part- 
time jobs or working during the semester breaks, which, in turn was conducive for local media firms to acquire and accumulate knowledge (Bathelt 2002).

In 1998, a joint bureau for start-up consulting and finance (ugb- the Unternehmensgründerbüro) was established by the Leipziger Sparkasse (an important local bank), the City and County of Leipzig and an industry association. The state programs, such as Saxony's Filmförderung, provided financial support for film festivals and European Social Fund of the European Union provided financial support for start-ups (Bathelt 2002). These initiatives served to establish an attractive environment for new entrants and spinoffs, which played an important role to reinforce the imprint of MDR.

In 2000, the Media City Leipzig was established as an incubator and technology center with 36,000 m2 of office space, workshop and studio space for TV and film-related firms (Schubert, 1999; 2000). The facilities provided not only working areas for firms but opportunities for interfirm communication, knowledge transfer and interactive problem solving. Furthermore, MDR also forced its subcontractors and suppliers to establish their business in the Media City (Bathelt, 2002). In addition to Media City Leipzig, the media center called The Medienhof Leipzig-Stötteritz housed 20 firms and Business \& Innovation Centre Leipzig (BIC Leipzig) in Leipzig-Plagwitz provided workspace mostly for start-ups (Schubert, 1999, 2000).

Moreover, in the private media clubs, which primarily limited their user base to media people, professionals from media industry gathered after work and shared their ideas, discussed various issues related to project Bathelt (2002). Thus, it is probable that these business circles acted as an incubator for new knowledge creation and new start-ups.

\section{CONCLUSION}

As we have discussed in the previous parts, existing explanations about regional clusters fail to offer vivid mechanisms by which historical unfolding of clusters in different regions are explicated. Although recent approaches like MLIT provide us with fairly satisfactory explanations, their analyses are often too generalized and do not adequately address how clusters, made up of multiple interactive firms evolve or do not evolve over historical time. In this vein, we synthesized the theoretical model of Marquis and Tilcsik (2013) by classical GD motor - variation, selection, retention- to represent how clusters evolve and which environmental and hereditary factors determine such evolution. By opening the black box of MLIT, the model explains how the history influences the sustained configuration of spatial economic activity.

Our historical comparative analyses of two empirical case studies -Pinch and Henry's BMSI and Bathelt and Boggs's LMGsignificantly corroborated our theoretical insights and displayed a considerable fit with our proposed analytical model. The summary of our findings about each case in terms of their evolutionary dynamics are presented in Table 5. In the case of BMSI, Pinch and Henry (1999) highlighted the origins and development of motorsport industrial cluster and provided crucial insights on key elements. As being a creative industry, it is not surprising to observe the important role of changes in the technological trajectories and effects of knowledge dissemination among firms. Nevertheless, the case of British Motor Sport Industry fits our synthetic imprinting model and provides information on the variation, selection and reinforcing mechanisms. Replacement of the qualified workforce (designers, engineers etc.) from aviation industry was the source of variation in the technological know-how of few firms and as the superior know-how diffused among firms of the cluster, it subsequently changed the whole motor sports industry. The know-how change should be understood as a change in the replicators of initially varied forms, which were selected by the environment because of their superior performance. WOI opened after the Mercedes accident was more effectively leveraged by BSMI instead of Italian motor sports industry due to the technological superiority acquired from aerospace industry. Spin-offs and other knowledge dissemination mechanisms among the pioneering firms of the BMSI acted as a retention mechanism as the superior replicators diffused among all firms in the cluster, entirely transforming them.

The second case written by Bathelt and Boggs (2003) was composed of three episodes, each of which contained different sensitive and insensitive periods on their own. All three episodes provided valuable information about the mediating factors and reinforcing mechanisms to solidify our synthetic model.

During the born of early stage book publishing industry, the main technological development was the invention of Gutenberg's moveable-type printing press. This technological trajectory created a sensitive period, opened a WOI and led to the flourishing of publishing industry in Leipzig instead of Frankfurt, which was closer to Mainz where new technology was invented. Same trajectories with similar favorable initial conditions resulted in two different ends. The main reason behind the difference was the presence of a heredity factor (specialization in German texts) at the time of sensitive period. Being close to protestant reform movement favored publishers clustered in Leipzig and German text, whereas Frankfurt's book fair was mostly dominated by Latin 
texts with International participants. The demand condition established in the sensitive period of technological change worked against the publishers in Frankfurt, which lacked necessary replicators, and mediated the selection of Leipzig cluster.

Having its $80 \%$ of physical plants destroyed and skilled labors relocated after the World War II, book publishing industry in Leipzig was never restored despite the several initiatives. Moreover, during GDR, nationalization, censorship and U.S. attraction disintegrated the remaining skilled workers from Leipzig and book publishers in Leipzig become technologically underdeveloped and poorly equipped compared to their Western competitors. In 1990, after German Reunification, a program was initiated for re-development of the book publishing industry in Graphisches Viertel but this program failed. But why did not this favorable political condition turn into a stamp on book publishing? The reason behind malfunction of the environmental condition in this sensitive period was the absence of a successful VSR mechanism. Book publishing industry in Leipzig was suffering not only from the lack of necessary skilled workforce, but also technological infrastructure. Thus, the initiative could not create a sufficient variation, which could result in the positive selection of pioneering firms. The resource and capability sets of existing firms in Leipzig could not absorb the variation and the WOI was not even opened for them.

Another political initiative after German Reunification was the establishment of MDR, the public television and broadcasting network. This initiative did not intend to establish an industry at all. The establishment of MDR in Leipzig was the result of a political move, which triggered the establishment of a new media industry in Leipzig. MDR became the anchor organization in the cluster by outsourcing its functions to local suppliers, attracting media specialists from other regions and forcing them to establish their branches in Leipzig. In this process, not only higher education institutes, special training programs and joint research projects but also start-ups supported by incubators acted to reinforce the stamp of MDR. Moreover, MDR was the vehicle that facilitated the imprint of political interference and acted as a selection mechanism itself. This type of evolutionary mechanism much more suits to example the Wrightian (Genetic) Drift. In genetic drift, replication that does not depend on environmental fitness, and like in the example of MDR, it is much more related to the 'founder organization'.

The Leipzig media cluster case shows that political decisions has intended or unintended consequences. Both resurrecting efforts for Leipzig's book publishing industry and establishment of MDR were local political decisions. Both cases show us that the imprinting model should be revisited to include political influencers as another branch of the environmental sources of imprinting. By this way, environment could be conceptualized in a richer and deeper manner. Moreover, our cases illustrated that sensitive periods do not automatically result in evolution of a cluster. In order for a cluster to evolve during a sensitive period is the presence of a VSR mechanism. VSR mechanism, on the other hand, is found to be affected by both environmental factors and genetic/hereditary factors. Thus, we argue that in order to explain the evolution of clusters in historical time, a synthetic approach, which combines multiple imprinting theory and generalized Darwinism is beneficial. 
Table 5: Summary of Case Findings

\begin{tabular}{|c|c|c|c|c|c|}
\hline Case & Sensitive Period & \begin{tabular}{|l|} 
Environmental \\
Influencer
\end{tabular} & Variation & Selection & Retention \\
\hline $\begin{array}{l}\text { Birth and growth of } \\
\text { BMSI }\end{array}$ & Post WWII era & $\begin{array}{l}\text { Technological shift } \\
\text { originated mostly } \\
\text { from aerospace } \\
\text { industry }\end{array}$ & $\begin{array}{l}\text { Recruitment of } \\
\text { skilled engineers } \\
\text { and designers from } \\
\text { aerospace industry } \\
\text { by BMSI created } \\
\text { the variation }\end{array}$ & $\begin{array}{l}\text { Know-how } \\
\text { acquired from } \\
\text { aerospace } \\
\text { connections } \\
\text { created a } \\
\text { supremacy and } \\
\text { increased the } \\
\text { fitness of BSMI }\end{array}$ & $\begin{array}{l}\text { Knowledge } \\
\text { disseminators and } \\
\text { spin-offs }\end{array}$ \\
\hline $\begin{array}{l}\text { Upgrading Leipzig } \\
\text { Book Publishing } \\
\text { Industry as hub }\end{array}$ & $\begin{array}{l}\text { Technological shift } \\
\text { originated from } \\
\text { invention of } \\
\text { moveable-type } \\
\text { printing press }\end{array}$ & $\begin{array}{l}\text { Protestant } \\
\text { Reformation }\end{array}$ & $\begin{array}{l}\text { Leipzig's book } \\
\text { printers were } \\
\text { specialized in } \\
\text { German dialect } \\
\text { texts and heretical } \\
\text { works, where } \\
\text { Frankfurt was } \\
\text { catered dominantly } \\
\text { to Latin texts }\end{array}$ & $\begin{array}{l}\text { Possessing cultural } \\
\text { proximity to } \\
\text { protestant } \\
\text { reformation helped } \\
\text { for publishers in } \\
\text { Leipzig to capture } \\
\text { the opportunity } \\
\text { and the local } \\
\text { industry become a } \\
\text { major location for } \\
\text { reformist printing }\end{array}$ & Apprenticeship \\
\hline $\begin{array}{l}\text { Restoring efforts } \\
\text { on book publishing } \\
\text { in Leipzig }\end{array}$ & $\begin{array}{l}\text { German re- } \\
\text { unification }\end{array}$ & $\begin{array}{l}\text { Political initiative to } \\
\text { restore the } \\
\text { industry }\end{array}$ & $\begin{array}{l}\text { Absence of } \\
\text { variation defuse } \\
\text { the stamp of } \\
\text { environmental } \\
\text { influence }\end{array}$ & $\mathrm{N} / \mathrm{A}$ & N/A \\
\hline $\begin{array}{l}\text { Birth of new media } \\
\text { industry in Leipzig }\end{array}$ & $\begin{array}{l}\text { German re- } \\
\text { unification }\end{array}$ & $\begin{array}{l}\text { Political move } \\
\text { unaffiliated with an } \\
\text { intent to build a } \\
\text { cluster }\end{array}$ & $\begin{array}{l}\text { Establishment of } \\
\text { MDR }\end{array}$ & $\begin{array}{l}\text { Selection was } \\
\text { intensively } \\
\text { connected to } \\
\text { relationship with } \\
\text { MDR }\end{array}$ & $\begin{array}{l}\text { Both localized } \\
\text { learning and spin- } \\
\text { offs }\end{array}$ \\
\hline
\end{tabular}

\section{REFERENCES}

Abbott, A. (1995). Sequence analysis: new methods for old ideas. Annual review of sociology, 21(1), 93-113.

Abernathy, W. J., \& Utterback, J. M. (1978). Patterns of industrial innovation. Technology review, 80(7), 40-47.

Amin, A. (1999). An institutionalist perspective on regional economic development. International journal of urban and regional research, 23(2), 365-378.

Aoki, M. (2000). Institutional evolution as punctuated equilibria. Chapters. In: Institutions, Contracts and Organizations, Edward Elgar Publishing Arthur, W. B. (1983). On competing technologies and historical small events: the dynamics of choice under increasing returns.

Aston, B., \& Williams, M. (1996). Playing to win: the success of UK motorsport engineering. Institute for Public Policy Research.

Audretsch, D. B., \& Feldman, M. P. (1996). Innovative Clusters and the Industry Life Cycle. Review of industrial organization, $11(2), 253-273$.

Bach, J. (1995). Was aus den DDR Verlagen geworden ist (What happened to the G.D.R. publishers). Frankfurter Allgemeine Zeitung 12 December

Bathelt, H. (2001). Regional Competence and Economic Recovery: Divergent Growth Paths in Boston's High Technology Economy. Entrepreneurship Regional Development, 13(4), 287-314.

Bathelt, H. (2002). The Re-Emergence of a Media Industry Cluster in Leipzig. European Planning Studies, 10(5), 583-611. 
Bathelt, H., \& Boggs, J. S. (2003). Toward a Reconceptualization of Regional Development Paths: Is Leipzig's Media Cluster a Continuation of or a Rupture with the Past? Economic Geography, 79(3), 265-293.

Bathelt, H., \& Glückler, J. (2003). Toward a relational economic geography. Journal of Economic Geography, 3(2), 117-144.

Beinhocker, E. D. (2006). The origin of wealth: Evolution, complexity, and the radical remaking of economics. Harvard Business Press.

Belussi, F., \& Hervás-Oliver, J. L. (2016). Introduction: Unfolding cluster and industrial district evolution: into the future. In Unfolding Cluster Evolution (pp. 29-36). Routledge.

Bentele, G.; Liebert, T.; and Polifke, M. (2000). Medienstandort Leipzig III: Eine Studie zur Leipziger Medienwirtschaft 2000 (Leipzig as a location of the media industry III: A study of Leipzig's media economy 2000). Leipzig

Berg, L.; Braun, L.; and v. Winden, W. (2001). Growth clusters in European metropolitan cities. A comparative analysis of cluster dynamics in the cities of Amsterdam, Eindhoven, Helsinki, Leipzig, Lyon, Manchester, Munich, Rotterdam and Vienna. Aldershot, Burlington, USA: Ashgate

Boggs, J. (2001). Path dependency and agglomeration in the German book publishing industry. Paper presented at the Annual Meeting of the Association of American Geographers, New York

Boschma, R., \& Frenken, K. (2003). Evolutionary Economics and Industry Location. Review of Regional Research, 23(2), 183-200.

Boschma, R., \& Frenken, K. (2006). Why Is Economic Geography Not an Evolutionary Science? Towards an Evolutionary Economic Geography. Journal of Economic Geography, 6(3), 273-302.

Boschma, R., \& Martin, R. (2007). Constructing an Evolutionary Economic Geography. In: Oxford University Press.

Boschma, R., \& Martin, R. (2010). The Aims and Scope of Evolutionary Economic Geography. Retrieved from

Boschma, R., \& Van der Knaap, G. A. (1997). New Technology and Windows of Locational Opportunity. Indeterminacy, Creativity and Chance. In In: J. Reijnders (Ed.). Economics and Evolution: Edward Elgar.

Boschma, R., \& Van der Knaap, G. A. (1999). New High-Tech Industries and Windows of Locational Opportunity: The Role of Labour Markets and Knowledge Institutions During the Industrial Era. Geografiska Annaler: Series B, Human Geography, 81(2), 73-89.

Börsenblatt (1993). Verlage der früheren DDR im Überblick: Übernahmen, Beteiligungen, Liquidationen (Publishers of the former G.D.R.: Mergers, acquisitions, closures). Börsenblatt 5 January, 53-54.

Breschi, S., \& Malerba, F. (2001). The geography of innovation and economic clustering: some introductory notes. Industrial and corporate change, 10(4), 817-833.

Camagni, R. (1991) Local 'Milieu', Uncertainty and Innovation Networks: Towards a New Dynamic Theory of Economic Space. In: Camagni, R., Ed., Innovation Networks: Spatial Perspectives, Belhaven, London, 121-144

Capello, Roberta. (2011). Location, Regional Growth and Local Development Theories. Aestimum: Firenze University Press

Carroll, G. R., \& Hannan, M. T. (1989). Density delay in the evolution of organizational populations: A model and five empirical tests. Administrative Science Quarterly, 34(3).

Chernow, R. (1998). Titan: The life of John D. Rockefeller, Sr.

Denzer, V., and Grundmann, L. (1999). Das Graphische Viertel - ein citynahes Mischgebiet der Stadt Leipzig im Transformationsprozeß: Vom Druckgewerbe- zum Bürostandort (The transformation of Leipzig's Graphical Quarter: From printing and publishing to modern office functions). Europa Regional 7(3):37-50

Dittmar, J. (2011). Information Technology and Economic Change: The Impact of The Printing Press. The Quarterly Journal of Economics. 126.

Dobbin, F. (1994). Forging industrial policy: The United States, Britain, and France in the railway age. Cambridge university press.

Dopfer, K., Foster, J., \& Potts, J. (2004). Micro-meso-macro. Journal of evolutionary economics, 14(3), 263-279.

Dosi, G. (1997). Opportunities, incentives and the collective patterns of technological change. The economic journal, 107(444), $1530-1547$.

Essletzbichler, J. (2012). Generalized Darwinism, Group Selection and Evolutionary Economic Geography. Zeitschrift für Wirtschaftsgeographie, 56(1-2), 129-146.

Essletzbichler, J., \& Rigby, D. (2005a). Competition, variety and the geography of technology evolution. Tijdschrift voor economische en sociale geografie, 96(1), 48-62.

Essletzbichler, J., \& Rigby, D. L. (2005b). Technological evolution as creative destruction of process heterogeneity: evidence from US plant-level data. Economic Systems Research, 17(1), 25-45. 
Essletzbichler, J., \& Rigby, D. L. (2007). Exploring Evolutionary Economic Geographies. Journal of Economic Geography, 7(5), 549-571.

Frenken, K., \& Boschma, R. A. (2007). A theoretical framework for evolutionary economic geography: industrial dynamics and urban growth as a branching process. Journal of economic geography, 7(5), 635-649.

Gormsen, N. (1996). Leipzig - Stadt, Handel, Messe: Die städtebauliche Entwicklung der Stadt Leipzig als Handels- und Messestadt (Leipzig's development as a trade and exhibition center). Leipzig: Institut für Länderkunde

Gould, N. E. S. J., \& Eldredge, N. (1972). Punctuated equilibria: an alternative to phyletic gradualism. Essential readings in evolutionary biology, 82-115.

Griliches, Z. (1957). Hybrid corn: An exploration in the economics of technological change. Econometrica, Journal of the Econometric Society, 501522.

Gräf, P. (2001). Das Buchverlagswesen und seine Standorte (The German book publishing industry). In Nationalatlas Bundesrepublik Deutschland: Band 9. Verkehr und Kommunikation, ed. Institut für Länderkunde, 116-117. Heidelberg, Berlin: Spektrum.

Hodgson, G. M. (2001). How Economics Forgot History: The Problem of Historical Specificity in Economics: London and New York: Routledge.

Hodgson, G. M. (2002). Darwinism in economics: from analogy to ontology. Journal of evolutionary economics, 12(3), 259-281.

Hodgson, G. M., \& Knudsen, T. (2006). Why We Need a Generalized Darwinism: And Why Generalized Darwinism Is Not Enough. Journal of Economic Behavior \& Organization.

Hodgson, G. M., \& Knudsen, T. (2010). Darwin's Conjecture: The Search for General Principles of Social and Economic Evolution: University of Chicago Press.

Hull, D. L., Langman, R. E., \& Glenn, S. S. (2001). A general account of selection: Biology, immunology, and behavior. Behavioral and brain sciences, 24(3), 511-528.

Johnson, V. (2007). What is organizational imprinting? Cultural entrepreneurship in the founding of the Paris Opera. American Journal of Sociology, 113(1), 97-127.

Jones, G., \& Khanna, T. (2006). Bringing history (back) into international business. Journal of International Business Studies, 37(4), 453-468.

Karrasch, I. (1989). Verlagswesen und Buchhandel in der DDR (Book trade and publishing in the G.D.R.). Unpublished Diplomarbeit. Stuttgart: Studiengang Verlagswirtschaft und Verlagsherstellung, Fachhochschule für Druck.

Klepper, S. (1996). Entry, exit, growth, and innovation over the product life cycle. The American economic review, 562-583.

Krätke, S., and Scheuplein, C. (2001). Produktionscluster in Ostdeutschland (Production clusters in East Germany). Hamburg: VSA

Krugman, P. (1991). Increasing returns and economic geography. Journal of political economy, 99(3), 483-499.

Lemke, R. (1992). Verlagswesen und Buchhandel im Osten Deutschlands - Versuch einer Bilanz im Frühjahr 1992 (Book trade and publishing in Eastern Germany - An evaluation). Internal document. Leipzig: Verband der Verlage und Buchhandlungen in Sachsen, Sachsen-Anhalt und Thüringen

Lounsbury, M. (2007). A tale of two cities: Competing logics and practice variation in the professionalizing of mutual funds. Academy of management journal, 50(2), 289-307.

Lucas Jr, R. E. (1988). On the mechanics of economic development. Journal of monetary economics, 22(1), 3-42.

Lundvall, B. A. (1992). National systems of innovation: An analytical framework. London: Pinter.

Mahoney, J. (2000). Path dependence in historical sociology. Theory and society, 29(4), 507-548.

Mahoney, J., \& Rueschemeyer, D. (Eds.). (2003). Comparative historical analysis in the social sciences. Cambridge University Press.

Maillat, D., Quévit, M., \& Senn, L. (1993). Réseaux d'innovation et milieux innovateurs. Réseaux dinnovation et milieu innovateurs: un pari pour le développement regional. Paris: GREMI/EDES.

Marquis, C. (2003). The Pressure of the Past: Network Imprinting in Intercorporate Communities. Administrative Science Quarterly, 48(4), 655689.

Marquis, C., \& Huang, Z. (2010). Acquisitions as exaptation: The legacy of founding institutions in the US commercial banking industry. Academy of Management Journal, 53(6), 1441-1473.

Marquis, C., \& Tilcsik, A. (2013). Imprinting: Toward a Multilevel Theory. Academy of Management Annals, 7(1), 195-245. 
Martin, R., \& Sunley, P. (2006). Path Dependence and Regional Economic Evolution. Journal of Economic Geography, 6(4), 395-437.

Martin, R., \& Sunley, P. (2001). Rethinking the “Economic" in Economic Geography: Broadening Our Vision or Losing Our Focus? Antipode, 33(2), 148-161.

Martin, R., \& Sunley, P. (2006). Path dependence and regional economic evolution. Journal of economic geography, 6(4), 395-437.

Martin, R., Sunley, P. (2015) On the notion of regional economic resilience: conceptualization and explanation, Journal of Economic Geography, 15(1): $1-42$

Martin, R., \& Sunley, P. (2017). The Post-Keynesian State and the Space Economy. Economy, 459-473

McEvily, B., Jaffee, J., \& Tortoriello, M. (2012). Not all bridging ties are equal: Network imprinting and firm growth in the Nashville legal industry, 1933-1978. Organization science, 23(2), 547-563.

Menz, G. 1942. Der Deutsche Buchhandel (The German book trade). 2nd ed. Gotha: Perthes.

Menzel, M.-P., \& Fornahl, D. (2009). Cluster Life Cycles-Dimensions and Rationales of Cluster Evolution. Industrial Corporate Change, 19(1), 205238.

Nelson, R. (1995). Recent Evolutionary Theorizing About Economic Change. Journal of economic literature, 33(1), 48-90.

Nelson, R., \& Winter, S. (1974). Neoclassical vs. evolutionary theories of economic growth: critique and prospectus. The Economic Journal, 84(336), 886-905.

Nelson, R., \& Winter, S. (1982). An Evolutionary Theory of Economic Growth. Belknap-Harvard, Cambridge, MA.

Neuman, W. L., \& Robson, K. (2014). Basics of social research. Toronto: Pearson Canada.

North, D. C. (1990). Institutions, Institutional Change and Economic Performance. In. Cambridge: Cambridge university press.

Perroux, François (1955): Note sur la notion de poles croissance. Economic Appliquee, 1 \& 2:307-320 (Translated by Mette Monsted, (1974)

Pettegree, A. (2017). The Reformation as a Media Event. Archiv für Reformationsgeschichte-Archive for Reformation History, 108(1), $126-133$.

Pinch, S., \& Henry, N. (1999). Paul Krugman's Geographical Economics, Industrial Clustering and the British Motor Sport Industry. Regional Studies, 33(9), 815-827.

Porter, M. E. (1990). The Competitive Advantage of Nations. London: Macmillan.

Porter, M. E. (1998). Clusters and Competition: New Agenda for Companies, Governments and Institutions. In On Competition. Boston, MA: Harvard Business School.

Pouder, R., \& St. John, C. H. (1996). Hot spots and blind spots: Geographical clusters of firms and innovation. Academy of management review, 21(4), 1192-1225.

Price, G. R. (1995). The Nature of Selection. Journal of Theoretical Biology, 175(3), 389-396.

Raynard, M., Lounsbury, M., \& Greenwood, R. (2013). Legacies of logics: Sources of community variation in CSR implementation in China. In Institutional Logics in Action, Part A (pp. 243-276). Emerald Group Publishing Limited.

Rigby, D. L., \& Essletzbichler, J. (1997). Evolution, process variety, and regional trajectories of technological change in US manufacturing. Economic Geography, 73(3), 269-284.

Rigby, D. L., \& Essletzbichler, J. (2006). Technological Variety, Technological Change and a Geography of Production Techniques. Journal of Economic Geography. 6. 45-70.

Romer, P. M. (1986). Increasing returns and long-run growth. Journal of political economy, 94(5), 1002-1037.

Rueschemeyer, D., \& Stephens, J. D. (1997). Comparing historical sequences-A powerful tool for causal analysis. A reply to John Goldthorpe's current issues in comparative macro-sociology. Comparative Social Research, 16, 55-72.

Sagurna, M. (2000). Der Medienstandort Leipzig im Freistaat Sachsen (Leipzig's role as a media location in Saxony). In Medienstadt Leipzig: Vom Anspruch zur Wirklichkeit, ed. H. Grunau, W. Kleinwächter und H.-J. Stiehler, Leipzig: Monade, 22-30.

Schönstedt, E. (1991). Der Buchverlag (The book publishing firm). Stuttgart: Metzler-Poeschel

Schubert, D. (1999). Media city-Leipzig: Bestandsaufnahme und Ausblick (Media city Leipzig: present state and future perspectives), in O. Altendorfer and K. Mayer (Eds) Sächsisches Medienjahrbuch 1998/1999, pp. 20- 23. Leipzig: Verlag für Medien \& Kommunikation. 
Schubert, D. (2000). Die Stadt Leipzig und die Medien als Wirtschaftsfaktor (The city of Leipzig and the economic importance of media). In Medienstadt Leipzig: Vom Anspruch zur Wirklichkeit, ed. H. Grunau, W. Kleinwächter und H.-J. Stiehler, 33-36. Leipzig: Monade.

Schulz, G. (1989). Buchhandels-Ploetz (Ploetz book trade directory). 4th ed. Freiburg: Ploetz

Sober, E., \& Wilson, D. S. (1998). Unto Others: The Evolution and Psychology of Unselfish Behavior Cambridge MA: Harvard University Press Cambridge.

Stinchcombe, A. L. (1965). Social Structure and Organizations. In Handbook of Organizations (Vol. 44, pp. 142-193).

Storper, M. (1997). The regional world: territorial development in a global economy. Guilford press.

Swaminathan, A. (1996). Environmental Conditions at Founding and Organizational Mortality: A Trial-by-Fire Model. Academy of Management journal, 39(5), 1350-1377.

Ter Wal, A. L., \& Boschma, R. (2011). Co-evolution of firms, industries and networks in space. Regional studies, 45(7), 919-933.

Volpers, H. (1991). Der gesamtdeutsche Buchmarkt 1990/91: Eine Bestandsaufnahme - ein Jahr nach der Vereinigung (The German book market in 1990/91: An evaluation one year after Reunification). Media Perspektiven 11:735-743

Weber, A. (1909). Über Den Standort Der Industrien. Tübingen: Mohr.

Weidhaas, P. (2009). The Frankfurt book fair: 60 years and still a shining example. Publishing research quarterly, 25(1), 30-35.

Wittmann, R. (1999). Geschichte des deutschen Buchhandels (History of the German book trade). 2nd ed. Munich: Beck.

Yin, R. K. (2003). Case study research: Design and methods (Vol. 5). 